Traffic Violations and Cooperative Intentions among Drivers: The Role of Corruption and Fairness

Word Count: 9342

\author{
JUSTICE TANKEBE \\ Institute of Criminology, University of Cambridge \\ Sidgwick Avenue, Cambridge CB3 9DA UK \\ * Direct Correspondence: jt340@cam.ac.uk
}

\author{
KOFI E BOAKYE \\ Department of Humanities and Social Sciences \\ Faculty of Arts, Law and Social Sciences \\ Anglia Ruskin University \\ East Rd Cambridge Campus, Cambridge CB1 1PT
}

MOSES AGAAWENA AMAGNYA

School of Criminology and Criminal Justice and Griffith Criminology Institute

Griffith University, Brisbane - Australia

176 Messines Ridge Road, Mt Gravatt Campus

QLD 4122, Australia 


\title{
Traffic violations and cooperative intentions among drivers: The role of corruption and fairness
}

\begin{abstract}
This paper examines traffic violations and cooperative intentions among a sample of commercial vehicle drivers in Ghana. Results show that personal and vicarious corruption experiences independently predict self-reported violations of traffic laws. We found no evidence that perceived police fairness influenced self-reported violations of traffic laws. However, perception of fairness correlates with self-reported violation of traffic laws only when it interacts with personal or vicarious corruption experiences. We also found that perceived police fairness significantly increased the likelihood of cooperation with police, lending support to evidence from prior studies. Personal experience of police corruption decreased the likelihood of cooperative intention. Perceived fairness remained relevant for cooperative intention even among drivers who report personal corruption experience. The implications of these findings are discussed.
\end{abstract}

Key words: legitimacy; procedural fairness; traffic violations; corruption; cooperation with police 


\section{Introduction}

In this study, we investigate the role of legitimacy in shaping both traffic violations and the willingness of motorists to assist the police to tackle such violations. Traffic fatalities are a major global problem; in its latest report on road safety, the World Health Organization (WHO) estimated 1.25 million deaths per year of which 90 percent are in the global south (WHO 2018). The report further noted that road traffic injuries will become the seventh leading cause of death by 2030 . Some of these fatalities arise from law-breaking behaviour by drivers including speeding, drunk-driving, and failure to wear seatbelts. Consequently, explaining why drivers break traffic laws becomes an urgent task not least because of the potential policy implications. Research evidence on factors that increase the likelihood of traffic rule-breaking can form the basis for policies to reduce the loss of human life and productivity through traffic accidents.

A key finding in this quest concerns beliefs about the normative statuses of rules such that people sometimes break laws because they do not consider them to be morally binding. Thus, as Hirschi put it, 'crime occurs because there is variation in the extent to which people believe they should obey the rules of society and, furthermore, that the less a person believes he should obey the rules, the more likely he is to violate them' (Hirschi 1969, p.26). This mechanism of legitimacy has attracted much empirical interest in recent years, starting from Tyler's (1990) ground-breaking work based on survey data from California. In China (Sun et al. 2017), the United States of America (Sunshine and Tyler 2003, Reisig et al. 2011), Britain (Jackson et al. 2012, Tankebe 2013), Australia (Murphy and Cherney 2012), Ghana (Tankebe 2009, Tankebe et al. 2016), Jamaica (Reisig and Lloyd 2009) and Trinidad and Tobago (Kochel et al. 2013), the research evidence shows that various dimensions of legitimacy - especially, fair treatment - explain some of the variations between individuals in their law-breaking behaviours. 
The current paper investigates the role of legitimacy in explaining traffic violations and the willingness of drivers to assist police to maintain order on the roads. In this way, it adds to a small body of literature that focuses on legitimacy effects in a specific area of public regulations such as those on traffic regulations (e.g. Engel 2005, Mazerolle et al. 2013, Hertogh 2015, MacQueen and Bradford 2015, Bates et al. 2016). A context-specific approach allows us to establish the areas of public regulation where legitimacy might be important and those areas where it might be less important. To our knowledge, this study is the first quantitative analyses of potential effects of legitimacy on traffic violations in an African context. Prior studies show that corruption is a stable feature of police interactions with motorists in some countries in Africa (see Foltz and Agyemang-Opoku 2015, Beek 2017). This raises important questions about the role of fairness on behaviour in the context of corruption. Consequently, our examination of the legitimacy-behaviour relationship promises insights on how that relationship shapes out in an African context. The results have the potential to advance knowledge on cross-cultural applicability of legitimacy theories in criminology. The data for our study come from a survey of commercial vehicle drivers in Ghana. We investigate the role of perceived police fairness and of experiences of police corruption in shaping self-reported violations of traffic laws and the willingness of these drivers to cooperate with the police to maintain order on the roads.

\section{Legitimacy and public behaviour}

When individuals consider whether they should break the law in particular situations or cooperate with legal authorities, a number of mechanisms might explain their decisions. One of these is legitimacy. Legitimacy refers to "power that is acknowledged as rightful by relevant agents, who include power holders and their staff, those subject to the power and third parties whose support or recognition may help confirm it' (Beetham 2013, p.19). In Beyond Procedural Justice, Bottoms and Tankebe (2012) argued that legitimacy was best conceptualised as a 
continuous dialogue between power-holders (e.g. police officers) and their multiple audiences (e.g. victims, offenders, and motorists). They claimed that, although dialogues took different forms in different societies, it was possible to identify key normative expectations, the fulfilment of which was likely to elicit public recognition of the validity of power. Bottoms and Tankebe $(2012,2017)$ outlined a four-dimensional model of legitimacy: procedural justice, which concerns fairness of decision-making processes; distributive justice, which is the fairness of substantive outcomes and of the allocation of resources; lawfulness, which encapsulates adherence to the rule of law; and effectiveness in the use of authority to meet police objectives. In the current study, we explore a series of hypotheses linking aspects of police legitimacy to public law-breaking behaviour and to cooperative intentions.

\section{Fair treatment}

The first of our hypotheses concerns perceived fair treatment by police. According to Tyler's procedural justice theory, people form their views of the legitimacy of a police agency from how its officers treat them. As he put it,

Every encounter that the public have with the police, the courts and the law should be treated as a socialising experience that builds or undermines legitimacy. Each contact is a 'teachable moment' in which people learn about the law and legal authorities (Tyler 2011, p.257).

In Why People Obey the Law, Tyler (1990) outlined key components of fairness judgments: voice; neutrality; trustworthy motives and respect. Voice concerns opportunities for participation in decision-making processes; that is, whether people are offered the chance to tell their 'side of the story' before decisions are made (Lind and Tyler 1988, Tyler 1990). Neutrality captures the absence of bias or discrimination in decision-making and being seen to make decisions based on relevant accurate information (Hickman and Simpson 2003). 
Trustworthy motives are about perceived direction of intentionality of decisions. Police officers create an impression of being more concerned about their own bureaucratic priorities than they are of people's well-being. To the extent that people distrust the motives of officers, they will view police processes as unfair (Tyler and Huo 2002). Respect describes concerns about level of police courtesy towards citizens, such as whether police uphold people's rights and make them feel valued (Tyler 1990).

When police demonstrate all or some of these elements in their decision-making, the public tends to accept the decision, comply with the law, and express an intention to cooperate with the police by supplying them with information about crime in their local communities (e.g. Tyler 1990, Jackson et al. 2012). Procedural justice theory has been applied to traffic regulations, producing insights to show that fair treatment matters to motorists. Bates and colleagues surveyed 237 young drivers and found that perceptions of procedural justice decreased self-reported speeding (Bates et al. 2016). Drawing on survey data from 1182 Dutch drivers, Hertogh (2015) explored the role of procedural justice in explaining a range of behaviours, including speeding, illegal parking, drink-driving and use of a mobile phone while driving. The results showed that drivers with a greater perception of procedural justice of the Dutch Central Fine Collection Agency were more likely to comply with traffic rules but drivers who questioned the legitimacy of legal authorities and legal rules were more likely to break the law.

Evidence from field experimental studies corroborates these findings from correlational studies. For example, in an experimental study in Queensland (Australia), Mazerolle and her colleagues reported that drivers who interacted with officers trained in procedural justice were more likely than those in a control group to express intentions to comply with traffic laws (Mazerolle et al. 2013). However, in Brisbane (Australia), Murphy and Mazerolle (2018) found that the effects of procedural justice on the willingness of immigrant drivers to cooperate with 
the police were contingent on the age of the drivers. Specifically, young immigrant drivers exposed to procedural justice treatment expressed a greater willingness to report crimes to the police than their counterparts who were exposed to 'control conditions'. Further, MacQueen and Bradford's (2015) study in Scotland did not fully replicate the Queensland findings by Mazerolle and her colleagues. Their analysis of survey data from 816 drivers found no evidence that procedural justice improved feelings of duty to obey traffic police officers. In reflecting on these unexpected findings, MacQueen and Bradford (2015, p. 436) noted, among other reasons, the longer duration of the Scotland traffic stops, and that officers might have been 'more scripted and "bureaucratised" in their interactions with the drivers. As they concluded, procedural justice per se might be insufficient to change people's orientations towards the law and legal authorities. ${ }^{1}$

Other experimental studies have used video vignettes about traffic stops. Reisig et al. (2018) used data from a factorial design study to test the effects of procedural injustice by police officers in the contexts of traffic stops and noise complaints among a sample of undergraduate students in the United States. They found that exposure to procedural injustice undermined the propensity to accept police decisions and to comply with directives by officers. Similarly, Maguire et al. (2016) tested the effects of fair treatment by showing videos of procedurally just and procedurally unjust traffic encounters to a sample of undergraduate students at universities in the United States. Consistent with other studies, trust in the police and willingness to cooperate with the police were greater among students who viewed procedurally just videos than those viewing procedurally unjust videos. Barkworth and Murphy (2015) have reported similar findings in Australia. Based on the procedural justice theory (fair treatment), we test two hypotheses:

Hypothesis 1A: The more drivers perceive police to be fair, the less likely they are to break traffic regulations. 
Hypothesis 1B: The more drivers perceive police to be fair, the greater the intention to cooperate with the police.

\section{Lawfulness}

Our second set of hypotheses concerns police lawfulness. Both Beetham (1991) and Coicaud (2002) identified lawfulness as an important dimension of legitimacy. For Beetham (1991, p.16), lawfulness is 'the first and most basic level of legitimacy'. It describes not only the legal source of power, but also the extent to which those in positions of authority act in accordance with established rules (Beetham 1991). Following Aristotle's negative approach, Bottoms and Tankebe (2012, pp.137-138) argue that the importance of police lawfulness for police legitimacy is best appreciated by exploring cases of police unlawfulness. They cite corruption in everyday interactions with citizens as one such negative instance. Corruption describes 'behaviour which deviates from the formal duties of a public role because of private-regarding (personal, close family, private clique), pecuniary or status gains; or violates rules against the exercise of certain types of private regarding influence' (Nye 1967, p.419).

Corruption manifests itself in diverse forms across different police forces (Ivkovic 2003, Kleinig 1996, Jauregui 2016). It includes bribery, under-enforcement and over-enforcement of laws on account of extra-legal considerations, suppression of criminal evidence and nepotistic exchanges (Roebuck and Barker 1974, Newburn 1999, Tankebe 2010). Corruption has been shown to undermine public feelings of obligation to obey the law (e.g. Jackson et al. 2014). However, in Nigeria, Akinlabi (2018) found that police unlawfulness did not influence people's felt obligation to obey the police nor their perceive moral alignment with police. Boateng (2018) reports similar findings from his cross-national analysis of the relationship between institutional corruption and trust in police. Analysing survey data from Ghana, Tankebe (2010) demonstrated that different experiences of corruption had different effects on confidence in the police; specifically, vicarious experiences of corruption were found to undermine confidence 
in the police, but direct experiences did not. Using data from factorial survey design in Ghana, Nivette and Akoensi (2017) found that people exposed to police corruption expressed dissatisfaction with the police.

A small number of studies have examined the role of police (un)lawfulness in shaping public cooperation with the police. Using survey data from Ghana, Tankebe (2009) found no evidence that experiences of police corruption influence intentions to cooperate with the police. Akinlabi (2018) also reported that in Nigeria, perceptions of police corruption were not associated with cooperative intentions. Analysing data on emergency calls to the police by residents of Milwaukee in the United States, Desmond et al. (2016) found that exposure to media reports of police misconduct reduced the likelihood of reporting crimes to the police. Another source of evidence on the effects of police unlawfulness comes from studies of 'legal cynicism'. Legal cynicism refers to 'a cultural frame in which people perceive the law as illegitimate, unresponsive, and ill equipped to ensure public safety' (Kirk and Papachristos 2011, p.1190). Using data from the United States, Kirk and Matsuda (2011) showed that legal cynicism reduced the likelihood of reporting offences to the police. From the same country, Reisig et al. (2011) found a correlation between legal cynicism and self-reported offending among university students. These mixed findings on how police unlawfulness shape public cooperation with the police therefore require further research. This present study tests the second set of hypotheses:

Hypothesis 2A: The more drivers experience police unlawfulness, the more likely they are to break traffic regulations.

Hypothesis 2B: The more drivers experience police unlawfulness, the less willing they will be to cooperate with the police. 


\section{Context of the current study}

Formal policing in Ghana was established in 1831 by British colonial administrators to aid the extraction of agricultural and mineral resources in the Gold Coast (Gillespie 1955, Tankebe 2008). Mistrust has been a trans-historical problem for the Ghana police. During colonial rule, police officers were 'hated as unaccountable representatives of an alien colonial power imposing a range of new laws and measures of social control which lacked any semblance of popular consent' (Killingray 1991, p.119). Suspicion and avoidance of, and disrespect for, police officers were reinforced by recruitment policies that drew upon 'outsiders' to police local communities (Gillespie 1955). Political independence in 1957 offered an opportunity to address legitimacy deficits and build trust in the police but political control of the police continues to obstruct efforts of democratisation (Tankebe 2008). Although colonial history continues to have some effect on police work in Ghana (see Boateng and Darko 2016), policing in Ghana today has become 'a patrimony of political and private elites' such that extra-legal factors sometimes influence police enforcement decisions, including arrests, investigations and prosecution of criminal offences (Tankebe 2013, p.584).

According to the 2018 Transparency International Perception Index, on a scale ranging from 0 ('highly corrupt') to 100 ('very clean'), Ghana received a score of 41 , which is similar to its 2017 score of 40 . These scores were however, the lowest in seven years, suggesting growing perceptions of institutional corruption in Ghana. Evidence from Freedom House (an international pro-democracy organisation) shows increasing consolidation of democratic culture in Ghana, although it highlights challenges with criminal justice agencies adherence to constitutional provisions on due process in criminal proceedings (Freedom House 2018). There is evidence of deep-seated public distrust and perception of police corruption. Results from the Afrobarometer (2017) survey showed that 58.6 percent of 2400 Ghanaians interviewed believed 
most or all police officers were corrupt. A similar proportion indicated they had little or no trust in police officers, with only $18 \%$ expressing high trust in officers. Beyond these general perceptions, media reports document cases of traffic police officers collecting bribes from drivers suspected of breaking rules (e.g. Daily Graphic 2017). Other reports show police use of abusive language, police violations of human rights, including beating of suspects, arrests without warrants, and police use of threats of prosecution as tools to extort bribes from drivers (Anim 2017, Myjoyonline 2018). It is within this context that we sought to understand how drivers experiences with the police influence their self-reported law-breaking behaviour and willingness to cooperate with the police.

\section{Methodology}

\section{Data}

The current study uses cross-sectional survey data derived from two of Ghana's major cities: Accra and Kumasi. Both cities have a number of transport terminals for intra-city and inter-city travels. The vehicles are privately owned and operated by a driver and a conductor - known locally as mate. Our study focused on the major terminals in the two cities: Nkrumah Circle (Accra) and Kejetia (Kumasi). In July 2015, two teams of four researchers each spent a fortnight at these terminals administering surveys to a convenience sample of drivers. Prior to administering the surveys, potential participants were informed that their participation was voluntary, and that their responses were completely anonymous. The study forms the baseline for a larger project tracking the experiences of commercial vehicles drivers for which we obtained ethical approval from the Institute of Criminology, University of Cambridge.

On average, each survey took 15 minutes to complete. A total of 415 drivers approached completed the survey, presenting a response rate of approximately $80 \% ; 2$ cases were not fully completed and were excluded from the analysis. Table 1 presents characteristics of the sample. Overall, 55.4\% came from Accra, and 21.2\% owned their vehicles; the majority of drivers 
$(80.5 \%)$ had basic education; $15 \%$ had been involved in a traffic crash and $82 \%$ had been stopped and questioned by police. Approximately, 51\% of these stops involved payment of bribes to the officers; a third of the stops resulted in no further action (NFA) by the officers. These would be cases in which the officers' suspicion of traffic offence was allayed; or, there were infractions, but officers chose non-enforcement due to a driver's show of deference (see Beek 2017, p.240).

\section{Measures}

The survey items measured five key variables: (i) self-reported traffic violations; (ii) cooperation with police; (iii) police fairness; (iv) personal experiences of corruption; and (v) vicarious experiences of corruption. With the exception of the single item on cooperation with police, we used a principal component analysis to extract the remaining four key constructs. These are presented in Appendix A. The Kaiser-Meyer-Olkin measure of sampling adequacy was .821 , which confirms the appropriateness of the data for such an analysis (see Hutcheson and Sofronniou 1999, p.224-225). Cronbach alpha coefficients for each of the scales were above the conventional cut-off point of .70 , indicating the strength of reliability of these scaled constructs.

\section{Traffic law-breaking}

This is the first of two dependent variables. It was measured with 10 items in which drivers were asked to reflect on their driving behaviour over the 6 months preceding the study. Examples of items were: 'You drove your car with no driving licence'; 'You drove your car faster than the speed limits ("over-speeding")'; and 'You failed to stop after a crash ("hit and run")'. These were measured on a four-point scale ranging from $1=$ Never to $4=$ Several times.

The 10 items were combined to create a 'traffic violation index', with a higher score indicating more frequent law-breaking behaviour (Cronbach's alpha $(\alpha)=.740 ; M=1.272 ; S D=.403$ ). 
The index was skewed (skewness $=2.545 ; \mathrm{SE}=.122$ ); we performed a log transformation that reduced the skewness (skewness $=1.452$ ). Our multivariate analysis below used the $\log$ transformation. However, we ran the analysis without the log transformation, and found no substantial differences (see endnote 3).

\section{Cooperation with police}

This was the second of our dependent variables, and it was measured with a single item: 'I am always willing to call the police to report traffic violations'. The response category ranged from $1=$ strongly disagree to $5=$ strongly agree $(M=3.459 ; S D=1.380)$, with a higher score representing increased willingness to cooperate with police.

Police unlawfulness. We measured police unlawfulness using items on experiences of police corruption. There is evidence to show that personal and vicarious experiences have different impact on people's perceptions and legal orientations (e.g. Tankebe 2010). We, therefore, measured personal and vicarious experiences of police corruption. Personal corruption experience captured those corrupt exchanges in which the drivers were the direct beneficiaries. Three items were used to measure this construct. These were: 'Someone (car owner, friends, or family, etc.) spoke to the police to stop your case from going to court ("foolish case")'; 'Someone (car owner, friends, or family, etc.) spoke to the police to stop your arrest for a traffic offence'; and 'Someone (car owner, friends, or family etc.) spoke to the police to release your vehicle to you'. The response to each question ranged from 1 = 'Never' to 4 = 'several times', a higher score representing more frequent personal experiences of police corruption $(\alpha=.886$; $M=1.552 ; S D=.901)$. Vicarious corruption experience was measured with five items tapping participants' knowledge of situations in which people have engaged in corrupt exchanges with the police. ${ }^{2}$ The items included: 'They paid the police money to avoid arrest for a traffic offence'; 'Someone (car owner, friends, or family, etc.) spoke to the police to stop their case 
from going to court'; and 'Someone (car owner, friends, or family, etc.) spoke to the police to stop them from being arrested for a traffic offence'. The response to each question ranged from $1=$ 'Never' to $4=$ 'several times' with a higher score indicating more frequent experiences of vicarious corruption $(\alpha=.893 ; M=2.328 ; S D=1.116)$.

\section{Fair treatment}

This was measured with six items drawn from empirical literature on fairness in policing (e.g. Sunshine and Tyler 2003, Tankebe et al. 2016). The items included 'Officers give me a reason for stopping me'; 'Officers listen to what I have to say during a traffic stop'; and 'Officers treat me with respect during a road traffic stop'. The response to each question ranged from $1=$ 'Strongly Disagree' to $5=$ 'Strongly Agree', with a higher score denoting more favourable perceptions of police fairness $(\alpha=.805 ; M=2.923 ; S D=.968)$.

\section{Analysis}

The analysis proceeded in three stages. First, we calculated the bivariate correlation between the hypothesised variables to establish direction and strength of the relationship. The second step was to estimate the relative importance of the hypothesised correlates. We focused on the $R^{2}$ and the beta coefficient results to establish the relative contribution of fairness and corruption experience to road traffic violations and cooperative intentions. Unlike demographic variables, establishing the relative importance of these hypothesised correlates can have significant policy implications in terms of changing perceptions and increasing cooperation with the police and reducing road traffic violations in Ghana. In the final step of the analysis we estimate separately the importance of conceptually similar variables and interaction terms for the key correlates (i.e., fairness, personal and vicarious experience of corruption) on the two outcome measures (road traffic violation and cooperative intentions). This helps us to establish the complex 
relationship (based on the beta coefficient results) and boundary conditions under which the hypothesised variables operate to influence road traffic violations and cooperative intentions with the police.

\section{Results}

Table 2 shows the bivariate correlations for all study variables. Personal experiences of corruption were significantly related to rule-breaking $(r=.210, p<.01)$ and cooperation with police $(r=-.213, p<.01)$, although both correlations were weak. Vicarious experiences of corruption were positively associated with rule-breaking $(r=.364, p<.01)$ and cooperation with police $(r=-.256, p<.01)$. Perceived police fairness showed a significant positive correlation with cooperation $(r=.364, p<.01)$ but not rule-breaking behaviour. Next, we estimated two linear regression models each for rule-breaking and cooperation with the police. Analysis of the correlates (both the VIF and the correlation results) showed no evidence of multicollinearity problems. However, to ensure the robustness of our results, we also ran separate regression models for personal and vicarious experiences of corruption as these were the only conceptually similar variables with a correlation above our conservative threshold of $r=.4$. The results for vicarious experiences are presented in Tables 4 and 6.

Table 3 about here

Table 3 presents results of ordinary least squares (OLS) regressions estimating the correlates of self-reported traffic violations. Model 1, which accounted for $7.8 \%$ of the variance, explored the main effects of the substantive hypothesised correlates. The results were consistent with our expectations. Specifically, we found that personal experiences of police corruption ( $\beta$ $=.186, p<.01)$ were positively associated with self-reported traffic violations. In other words, 
the more drivers reported personal corruption transactions with police officers, the more likely they were to report breaking traffic laws. As Table 4 shows, vicarious experiences of corruption produced similar effects on traffic violations $(\beta=.362, p<.001)$. However, in contrast to other studies (e.g. Hertogh 2015), perceptions of police fairness did not correlate with law-breaking behaviour. We also found that the more experienced the drivers were, the less likely they were to report breaking traffic laws $(\beta=.154, p<.01){ }^{3}$

Model 2 introduces interactions between the substantive correlates. This model explained $21.5 \%$ of the variance in traffic law-breaking behaviour. The results reported in Model 1 for perceived police fairness and vicarious corruption experience remained largely unchanged. However, personal experiences of corruption were statistically associated with frequent traffic violations, $p<.05$. Here again, similar vicarious experiences also increased traffic violations $(\beta=.363, p<.001)$; perceived treatment continued to show no statistically significant influence. Perhaps, strikingly, we found that perceptions of police fairness reached significance levels when it interacts with frequent personal experiences of corruption $(\beta=.227$, $p<.001)$, and with frequent vicarious experiences of corruption $(\beta=.183, p<.01$, Table 4$)$. However, the effect was to increase violations of traffic regulations.

\section{Table 4 about here}

To explore these counter-intuitive findings further, we compared the correlates of traffic violations across drivers whose interactions with police resulted in no further action by the police (NFA) to those whose interactions involved ending with payment of bribes (bribers). It emerged that the links between fairness and traffic violations reported above were concentrated among bribers (a table of results is available on request). Among this subgroup of drivers, 
perceived police fairness $(\beta=.212, p<.01)$ and personal corruption experience $(\beta=.211, p<$ .01) were each associated with increased frequency of self-reported traffic violations. When we introduced an interaction term between the two correlates, it was statistically significant $(\beta=$ $.247, p<.01)$ but the prior independent effects of perceived fairness disappeared. However, among the subsample of NFAs, neither perceived fairness nor corruption experiences correlated with self-reported traffic violations. For this group, a history of road accidents was the only statistically significant correlate of self-reported traffic violations.

\section{Table 5 about here}

Table 5 regresses drivers' willingness to cooperate with police on sociodemographic characteristics, personal corruption experiences, and perceived police fairness in Model 1. The model, which accounted for $22.5 \%$ of the variance in cooperative intentions, showed differences between drivers from two cities in their cooperative intentions. Among the substantive correlates, perceived police fairness was statistically significant correlate of cooperation with the police $(\beta=.331, p<.001)$; the more drivers perceived the police to be fair, the more inclined they were to cooperate with them. As predicted, experiences of police illegality in the form of corruption undermined the prospect of cooperation with police $(\beta=$ $.113, p<.05)$, but vicarious experiences, as shown in Table 6, exhibited no influence. In Model 2, we added interactions between personal experiences of corruption and perceived police fairness; we found that interaction to be statistically significant and positive, suggesting that the joint effects of experiencing corruption and fair treatment were an increase in cooperative intentions, $p<.01$. We found similar results in the interaction between perceived fairness and vicarious corruption experience (Table $6, \beta=.110, p<.05$ ). The model accounted for $24 \%$ of the variance in the intentions of drivers to cooperate with the police. 


\section{Discussion}

Societies face a perennial challenge; it is the double social-order challenge of ensuring that compliance with traffic laws and, if motorists are privy to violations by other motorists, they volunteer the information to law enforcement authorities. Legitimacy has emerged as a key mechanism for addressing this challenge. The evidence from various jurisdictions supports its influence on pro-social behaviours such as compliance and cooperation intentions (e.g. Murphy and Cherney 2012, Jackson et al. 2012, Tankebe et al. 2016). The goal of our study was an exploratory investigation of the correlates of law-breaking and cooperative intentions among commercial vehicle drivers in Ghana.

The first most important finding concerns the role of perceived police fairness. We found that, on their own, perceptions of police fairness had no influence on self-reported violations of traffic laws. This contradicts the dominant findings reported in the procedural justice literature (e.g. Bates et al. 2016, Hertogh 2015). However, the most striking of our findings was that an interaction between personal experiences of corruption and perceptions of police fairness increased the likelihood of self-reported law-breaking on the roads among the drivers surveyed. To our knowledge, Augustyn's (2015) study in the United States is the only correlational study to have reported counterintuitive results involving perceived police fairness: she analysed data from 1,354 adolescent offenders and found that judgments of procedural justice increased the frequency of offending among adolescent-onset offenders (p. 394). Augustyn (2015) conjectured that: 
Perhaps $[\ldots]$ positive evaluations of procedural justice with the police and courts indicate a lack of trepidation or fear of subsequent interactions with legal authorities. Beliefs that subsequent encounters with legal authorities will not be 'that bad' and the police and courts will treat one in a fair and respectful manner in the future may encourage rather than discourage offending (p. 397).

It is possible that this explanation applies to our findings. However, another possible explanation draws attention to the character of the officer-driver relationship. In her study of staff-prisoner relationships, Liebling (2011) differentiates between 'good' and 'right' relationships: the latter are professional and ethical relationships between staff and prisoners, while the former refers to relationships that are 'too close or too informal, lacking boundaries and professional distance' (Liebling 2011. p.491). As she found, 'good' relationships are sites for criminal conduct (see also Muscat 2015). Police officers in such relationships are akin to those that Muir (1977) describes as 'reciprocator': these are officers with a reputation of being 'Joe Good Guy' and a tendency to 'bestow upon the citizen the reciprocal of [their] authority, [their] leniency, the power not to hurt' in exchange for personal profit such as bribes (1977, p.293).

It is possible that the drivers we studied were dealing with reciprocal traffic officers, and the relationships they had were good rather than right. Reciprocal officers are not necessarily violent, certainly not like another of Muir's (1977) types of officers: enforcers. The reciprocal officer would likely listen to what drivers have to say, explain decisions, show care for drivers' well-being, and avoid discriminatory stops of drivers, yet choose not to enforce the law on account of extra-legal considerations (see: Beek 2017, p.236). However, the effect of such relationships might be to encourage criminal behaviour. Consequently, we find that the interaction term between personal corruption experience and perceived police fairness was associated with increased frequency of traffic violations. This finding that the behavioural 
consequences of experiences of procedural justice might depend on the character of police officers require further investigation before firm conclusion can be drawn.

However, and consistent with prior results about motorists (e.g. Mazerolle et al. 2013), we found that perceived fair treatment had a positive influence on the willingness of our commercial vehicle drivers to cooperate with the police. This finding, therefore, adds to the cross-cultural generalisability of Tyler's model of procedural justice. Yet, prima facie, it would appear counter-intuitive that perceived fair treatment might simultaneously increase the likelihood of offending and cooperative intentions among our sample of drivers. Here again, Muir's characterisation might help to address this apparent contradiction. According to Muir (1977):

The reciprocating response depended on nurturing the citizen's sense of personal obligation to the particular police officer. It depended on the officer's touching some personal compulsion of gratitude, on the return of favours (p. 144).

Within this framework, it is reasonable to expect drivers to volunteer information to such officers. As Beek (2017) concluded in his study of police interactions with drivers, the law may not constitute the only source of legitimacy:

Applying the law without regard to moral considerations is not necessarily deemed legitimate in Ghana. Overall, civilians do not ascribe legitimacy generally, but perceive it as highly situational and context based (Beek 2017, p.243).

In some situations, civilians expect 'fairness' in police reactions to violations of traffic rules, which are inevitable in a context where most commercial vehicles were in a 'blatant state of disrepair' (Beek 2017, p.233). Strict enforcement of road traffic laws comprising over 300 offences would paralyse the transport of goods and people. On this note, perception of fairness 
may mean police officers' tolerance of some types of traffic violations for which drivers show their 'appreciation'. As Beek notes (2017, p.244) 'some civilians shared the police officers' perception of the handover of money as a social act in the face of the law. I scratch your back you scratch mine'. What all this points to is the fragility of legitimacy and the necessity of perpetual dialogue to reinforce its essence in everyday encounters. In this context, failure to enforce the law may be perceived as fair, which in turn reinforces future traffic violations.

The second set of findings is associated with corruption in shaping traffic violations and cooperative intentions. We found that personal and vicarious experiences of corruption independently correlated with frequent violations of traffic laws and willingness to cooperate with the police. This correlation between criminal victimisation (corruption transactions with police) and criminal behaviour is consistent with criminological evidence on victim-offender overlap. That evidence shows that victims have a high probability of engaging in crime, and offenders are likely to be victims (Lauritsen and Laub 2007; Berg et al. 2012). However, it would seem reasonable to say the opposite was true in the present case: criminal behaviour correlated with criminal victimisation as drivers who broke the law appeared to have become vulnerable to police corruption. However, while we might judge them to be victims, drivers might not necessarily view themselves as such, especially if they initiated the corrupt transactions. As Tankebe (2010, p.310) argues, a claim of victimhood is 'less justifiable when citizens voluntarily seek to influence police decision in order to evade criminal liability or to obtain services otherwise inaccessible to their fellow citizens' (see also: Beek 2017).

An alternative explanation concerns the perceived risks of formal criminal sanctions. Evidence from deterrence research demonstrate that law-breaking is less likely if potential offenders believe there is a significant chance that criminal sanctions will apply to them if they are apprehended (von Hirsch et al. 1999, Wikström 2008). Thus, it would appear that the drivers 
we studied had learnt through personal or vicarious experience that it was possible to negotiate with individual police officers to avoid prosecution if they were arrested. A study by Foltz and Opoku-Agyemang (2015) shows drivers' experiences of corruption with traffic police in Ghana tends to escalate over time, both in frequency and volume of bribes. These payments often arise from police suspicion of traffic violations. Therefore, it would appear that the more corruption facilitated avoidance of prosecution, the more drivers were inclined to disobey traffic laws. However, although corruption experience may increase violation of traffic laws, evidence from recent studies suggest it may not necessarily translate into civilian satisfaction with the police even when the encounter is citizen initiated (Nivette and Akoensi 2017).

\section{Limitations and conclusion}

Although our study has several notable strengths such as a large sample size from two locations, the inclusion of multiple measures and controls, and robust analysis of the data, it is also important to note a number of limitations. First, our data came from a non-random sample, which limits the scope for generalisability. We have, therefore, been cautious in the conclusions drawn. For example, our study focused on commercial vehicle drivers who are only a subset of professional drivers. Future studies that draw on representative samples will help establish how robust our findings are and how far they extend to other professional drivers and road users. Second, we measured self-report rule-breaking, which might have been affected by 'social desirability bias'; that is, the tendency for participants to present themselves in positive light rather than share their true experiences (see Nederhof 1985). However, given the evidence from ethnographic accounts (e.g. Beek 2017), official records on traffic violations are bound to under-report these cases. It is, therefore, important for studies to explore innovative methods beyond self-report (e.g. video recording of such encounters) to capture the offences of public transport drivers. 
Third, we asked drivers about their perceptions of fairness and intentions to cooperate with the police in tackling traffic violations. Fairness is a subjective construct, and therefore difficult to measure objectively. Also we did not measure actual cooperative behaviour. Yet, results of systematic reviews of attitudinal-behaviour nexus show people display attitudes that do not always guide future behaviour (Glasman and Albarracin 2006). Hence, studies that measure actual cooperative behaviour would help establish the circumstances under which different dimensions of legitimacy shape driver behaviour. A related measurement issue concerns police unlawfulness. We used items that measured the drivers' experiences of police corruption. Given the reputation of the Ghanaian traffic police as a corrupt unit, which is often discussed in traditional and social media (see Ghanaweb 2019), it was possible that reports of vicarious experiences of corruption might not be factual. Conversely, some drivers might have under-reported their personal involvement in corrupt transactions with the police. The use of observational data might offer a solution to this measurement problem.

Finally, our study measured elements of only one criminological theory of criminal behaviour. Just like legitimacy, deterrence theory is also based on people's assessments of institutions. Evidence by Proirer et al. (2018) shows that, among young drivers in Quebec (Canada), delinquent peers, self-control, and perceptions of seriousness of traffic violations correlated with intentions to violate traffic laws. Beyond the context of road policing, Tankebe (2019) found that deterrence perceptions, rather than legitimacy, were the main correlates of the willingness of young Ghanaian adults to cooperate with the police against corruption. We did not measure deterrence and the other factors in the Quebec study, and it is important that future studies in the African context address this gap in our study.

Notwithstanding these limitations, the results from our study have important implications for future legitimacy research and for efforts to promote social order on the roads. Legitimacy researchers have not always considered how different elements of legitimacy 
interact to influence public behaviour. Our results show that such an exploration can produce significant insights that extend the literature on legitimacy. We have also shown that the influence of police fairness on behaviour is highly contextualised: a corrupt normative setting negates the influence of procedural fairness on law-breaking behaviour but not on cooperative intentions. This suggests the importance of considering the moral settings in future procedural justice research. It also permits caution against a view of procedural justice as 'general' theory of public behaviour. In terms of practical implications, our findings show that police can reduce traffic violations by curbing corruption among traffic officers. They may be able to increase the flow of information from commercial vehicle drivers by improving the fairness of their interactions with these drivers. More strategically, police managers can build legitimacy and harness its benefits for social order by investing in reforms that help develop and sustain right police-public relations.

\section{Notes}

1. In a follow-up study, MacQueen and Bradford (2017) explored how the officers experienced and perceived the expereiment. The data gave some insight into the possible reasons for the counterintuitive results (or contrary findings) reported. A key hypothesis was that, under conditions of organisational injustice, officers react negatively to management directives concernining procedural justice in police-public interactions. Thus, police managers cannot make officers champions of procedural justice if the officers are themselves denied fair treatment (see Tankebe 2014; Marks and Fleming 2006).

2. The research participants were asked to limit themselves to experiences with colleague drivers at their terminals. However, it is hard to tell whether they also drew upon media reports of traffic police corruption. 
3. When we ran the analysis without log transformation of our measure of self-reported traffic violations, levels of experience showed no statistically significant influence. Another differences was the proportion of the variance that the model explained: it was $13.4 \%$ for the non-log transformation model.

\section{Disclosure Statement}

No potential conflict of interest was reported by the authors

\section{References}

Afrobarometer. (2014, December 2). Trust and corruption in public institutions: Ghanaian opinions. Retrieved from http://www.cddgh.org/_upload/general/GHA_AB_R6_Dissemination3\%20(Trust\%20 \%20Corruption)_01dec_2014_FINAL.pdf[Accessed 5 May 2018].

Akinlabi, O. M. (2015). Young people, procedural justice and police legitimacy in Nigeria. Policing and Society, 27(4), 419-438

Akinlabi, O. M. (2018). Why do Nigerians cooperate with the police? Legitimacy, procedural justice and other contextual factors in Nigeria. In D. Oberwittler \& S. Roche (eds.), Police-citizen relations across the world: Comparing sources and contexts of trust and legitimacy (pp. 151-174). London: Taylor \& Francis.

Anim, R.K. (2017, September 23). The surge of police brutality in Ghana: A call to the Inspector General of Police to step up his game. Retrieved from https://www.modernghana.com/news/804694/the-surge-of-police-brutality-in-ghanaa-call-to-the-inspec.html [Accessed on 20 May 2018).

Augustyn M. B. (2015). The (ir)relevance of procedural justice in the pathways to crime. Law and Human Behaviour, 39(4), 388-401. 
Barkworth, J., \& Murphy, K. (2015). Procedural justice policing and citizen compliance behaviour: the importance of emotion. Psychology, Crime \& Law, 21(3), 254-273.

Bates, L., Allen, S., \& Watson, B. (2016). The influence of the elements of procedural justice and speed camera enforcement on young novice driver self-reported speeding. Accident Analysis \& Prevention, 92, 34-42.

Beek, J. (2017). Money, morals and law: The legitimacy of police traffic checks in Ghana. In J. Beek, M. Göpfert, O. Owen, \& J. Steinberg (Eds.), Police in Africa: The Street Level View (pp. 231-248). Oxford, UK: Oxford University Press.

Beetham, D. (1991). The legitimation of power (1st ed.). London: Palgrave Macmillan.

Beetham D. (2013). The legitimation of power (2nd ed.). Basingstoke: Palgrave Macmillan

Berg, M. T., Stewart, E. A., Schreck, C. J., \& Simons, R. L. (2012). The victim-offender overlap in context: Examining the role of neighborhood street culture. Criminology, $50(2), 359-390$.

Boateng, F. D. (2018) Police legitimacy in Africa: a multilevel multinational analysis, Policing and Society, 28(9): 1105-1120

Boateng, F. D., \& Darko, I. N. (2016). Our past: The effect of colonialism on policing in Ghana. International journal of police science \& management, 18(1): 13-20.

Bottoms, A. (2002). Morality, crime, compliance and public policy. In A. Bottoms \& M. Tonry (Eds.), Ideology, crime and criminal justice: A symposium in honour of Sir Leon Radzinowicz (pp. 20-51). Cullompton, UK: Willan.

Bottoms, A., \& Tankebe, J. (2012). Beyond procedural justice: A dialogic approach to legitimacy in criminal justice. The Journal of Criminal Law and Criminology, 102(1), 119-170. 
Bottoms, A., \& Tankebe, J. (2017). Police legitimacy and the authority of the state. In A. du Bois-Pedain, M. Ulväng, \& P. Asp. (Eds.), Criminal law and the authority of the state. Oxford, UK: Hart Publishing Limited.

Coicaud, J.-M. (2002). Legitimacy and politics: A contribution to the study of political right and political responsibility. Cambridge, UK: Cambridge University Press.

Daily Graphic (2017, October 16). 6 police officers caught taking money from drivers in trouble. Retrieved from http://citifmonline.com/2017/10/16/6-police-officers-caughttaking-money-from-drivers-in-trouble/ [Accessed 12 May 2018].

Desmond, M., Papachristos, A. V., \& Kirk, D. S. (2016). Police violence and citizen crime reporting in the black community. American Sociological Review, 81(5), 857-876

Engel, R. S. (2005). Citizens' perceptions of distributive and procedural justice during traffic stops with the police. Journal of Research in Crime and Delinquency, 42(4), 445-481.

Foltz, J. D., \& Opoku-Agyemang, K. A. (2015). Do higher salaries lower petty corruption? A policy experiment on West Africa's highways. IGC Working Paper. London, UK: International Growth Centre (IGC).

Freedom House. (2018). Freedom in the world 2018: Ghana profile. Retrieved from https://freedomhouse.org/report/freedom-world/2018/ghana [Accessed 12 May 2018]

Ghanaweb (2019) Police officer caught on camera taking bribes. Available at https://www.ghanaweb.com/GhanaHomePage/NewsArchive/Police-officer-caught-oncamera-taking-bribe-748020 [Accessed 10 June 2019]

Gillespie, W. H. (1955). The Gold Coast police, 1844-1938/with illustrations specially drawn by C.R. Edelsten and from other sources. Accra, Ghana: The Government Printer.

Glasman, L. R., \& Albarracin, D. (2006). Forming attitudes that predict future behaviour: A meta-analysis of the attitude-behaviour relation. Psychological Bulletin, 132(5), 778-822. 
Hertogh, M. (2015). What moves Joe Driver? How perceptions of legitimacy shape regulatory compliance among Dutch traffic offenders. International Journal of Law, Crime and Justice, 43(2), 214-234.

Hickman, L. J., \& Simpson, S. S. (2003). Fair treatment or preferred outcome? The impact of police behaviour on victim reports of domestic violence incidents. Law and Society Review, 37(3), 607-634.

Hirschi, T. (1969). Causes of delinquency. Berkeley, US: University of California Press.

Hutcheson, D. G., \& Sofronniou, N. (1999). The multivariate social scientist: Introductory statistics using generalized linear models. London: Sage Publications.

Ivković, S. (2003). To Serve and Collect: Measuring Police Corruption. The Journal of Criminal Law and Criminology (1973-), 93(2/3), 593-650

Jackson, J., Asif, M., Bradford, B., \& Zakria Zakar, M. (2014). Corruption and Police Legitimacy in Lahore, Pakistan. British Journal of Criminology, 54(6), 1067-1088.

Jackson, J., Bradford, B., Hough, M., Myhill, A., Quinton, P., \& Tyler, T. R. (2012). Why do people comply with the law? Legitimacy and the influence of legal institutions. British Journal of Criminology, 52, 1051-1071.

Jauregui, B. (2016). Provisional authority: Police, order, and security in India. Chicago, IL, University of Chicago Press.

Killingray, D. (1991). Guarding the extending frontier: Policing the Gold Coast, 1865-1913. In D. M. Anderson \& D. Killingray (Eds.), Policing the empire: Government, authority and control, 1830-1940 (pp. 106-125). New York, NY: Manchester University Press.

Kirk, D. S., \& Matsuda, M. (2011). Legal cynicism, collective efficacy, and the ecology of arrest. Criminology, 49, 443-472.

Kirk, D. S. \& Papachristos, A. V. (2011). Cultural mechanisms and the persistence of neighborhood violence. American Journal of Sociology, 116(4), 1190-1233. 
Kleinig, J. (1996). The ethics of policing. Cambridge, UK: Cambridge University Press.

Kochel, T. R., Parks, R., \& Mastrofski, S. D. (2013). Examining police effectiveness as a precursor to legitimacy and cooperation with police. Justice Quarterly, 30(5), 895925.

Lauritsen, J. L. \& Laub, J. H. (2007). Understanding the link between victimization and offending: New reflections on an old idea. Crime Prevention Studies 22, 55-75.

Liebling, A. (2011). Distinctions and distinctiveness in the work of prison officers: Legitimacy and authority revisited. European Journal of Criminology, 8(6), 484-499.

Lind, E. A., \& Tyler, T. R. (1988). Critical issues in social justice. The social psychology of procedural justice. New York, NY, US: Plenum Press.

MacQueen, S., \& Bradford, B. (2015). Enhancing public trust and police legitimacy during road traffic encounters: results from a randomised controlled trial in Scotland. Journal of Experimental Criminology, 11(3): 419-443.

MacQueen, S., \& Bradford, B. (2017). Where did it all go wrong? Implementation failure - and more - in a field experiment of procedural justice policing. Journal of Experimental Criminology, 13(3), $321-345$

Maguire, E. R., Lowrey, B. V., \& Johnson, D. (2017). Evaluating the relative impact of positive and negative encounters with police: A randomized experiment. Journal of experimental criminology, 13(3), 367-391.

Marks, M., \& Fleming, J. (2006). The right to unionize, the right to bargain, and the right to democratic policing. The Annals of the American Academy of Political and Social Science, 605(1), 178-199.

Mazerolle, L., Antrobus, E., Bennett, S., \& Tyler, T. R. (2013). Shaping citizen perceptions of police legitimacy: A randomized field trial of procedural justice. Criminology, 51(1), $33-63$.

Muir, W. K. (1977). Police: Streetcorner politicians. Chicago: University of Chicago Press. 
Murphy, K., \& Cherney, A. (2012). Understanding cooperation with police in a diverse society. British Journal of Criminology 52(1), 181-201.

Murphy, K., \& Mazerolle, L. (2018). Policing immigrants: using a randomized control trial of procedural justice policing to promote trust and cooperation. Australian and New Zealand Journal of Criminology, 51(1), 3-22.

Muscat, M (2015) Moral performance and ethical practices within Malta's main correctional facility. Unpublished M.Phil Dissertation. Institute of Criminology, University of Cambridge, United Kingdom.

Myjoyonline (2018, April 4). 17 Journalist attacked in 15 months: The sad story of safety of journalists in Ghana. Retrieved from https://www.myjoyonline.com/news/2018/April11th/17-journalists-attacked-in-15-months-the-sad-story-on-safety-of-journalists-inghana.php [Accessed 20 May 2018]

Nederhof, A. J. (1985). Methods of coping with social desirability bias: A review. European journal of social psychology, 15(3), 263-280.

Newburn, T. (1999). Understanding and Preventing Police Corruption: Lessons from the Literature. Police Research Series Paper 110. London, England: Home Office.

Nivette, A. E., \& Akoensi, T. (2017). Determinants of satisfaction with police in a developing country: A randomised vignette study. Policing and Society. Advance online publication. doi: 10.1080/10439463.2017.1380643.

Nye, J. S. (1967). Corruption and Political Development: A Cost-Benefit Analysis. The American Political Science Review, 61(2), 417-427

Proirer, B., Blais, E., \& Faubert, C. (2018). Graduated driver licensing and differential deterrence: The effect of license type on intentions to violate road rules. Accident Analysis \& Prevention, 110, 62-70. 
Reisig, M. D., \& Lloyd, C. (2009). Procedural justice, police legitimacy, and helping the police fight crime: Results from a survey of Jamaican adolescents. Police Quarterly, 12(1), $42-62$.

Reisig, M. D., Wolfe, S. E., \& Holfreter, K. (2011). Legal cynicism, legitimacy, and criminal offending: The non-confounding effect of low self-control. Criminal Justice and Behaviour, 38, 1170-1184.

Reisig, M. D., Mays, R. D., \& Telep, C. W. (2018). The effects of procedural injustice during police-citizen encounters: a factorial vignette study. Journal of Experimental Criminology, 14(1), 49-58

Sun, I. Y., Wu, Y., Hu, R., \& Farmer, A. S. (2017). Procedural justice, legitimacy, and public cooperation with police: Does western wisdom hold in China? Journal of Research in Crime and Delinquency, 54(4), 454-478.

Sunshine, J., \& Tyler, T. R. (2003). The role of procedural justice and legitimacy in shaping public support for policing. Law and Society Review, 37(3), 513-548.

Tankebe, J. (2008). Colonialism, legitimation, and policing in Ghana. International Journal of Law, Crime and Justice, 36(1), 67-84.

Tankebe, J. (2009). Self-help, policing, and procedural justice: Ghanaian vigilantism and the rule of law. Law and Society Review, 43(2), 245-269.

Tankebe, J. (2010). Public confidence in the police: Testing the effects of public experiences of police corruption in Ghana. British Journal of Criminology, 50(2), 296-319.

Tankebe, J. (2013). Viewing things differently: The dimensions of public perceptions of police legitimacy. Criminology, 51(1), 103-135.

Tankebe, J. (2014). The making of 'democracy's champions': Understanding police support for democracy in Ghana. Criminology \& Criminal Justice, 14(1), 25-43. 
Tankebe, J., Reisig, M. D., \& Wang, X. (2016). A multidimensional model of police legitimacy: A cross-cultural assessment. Law and Human Behaviour, 40(1), 11-22.

Tankebe, J. (2019) Cooperation with the Police Against Corruption: Exploring the Roles of Legitimacy, Deterrence and Collective Action Theories, The British Journal of Criminology, , azz030, https://doi.org/10.1093/bjc/azz030

Transparency International. (2017). Corruption perception index 2017. Berlin: Transparency International.

Transparency International. (2018). Corruption perception index 2018. Berlin: Transparency International.

Tyler, T. R. (1990). Why people obey the law. New Haven, CT: Yale University Press.

Tyler, T. R. (2011). Trust and legitimacy: Policing in the USA and Europe. European Journal of Criminology, 8, 254-266.

Tyler, T. R., \& Huo, Y. J. (2002). Trust in the law: Encouraging public cooperation with the police and courts. New York, NY: Russell-Sage Foundation.

von Hirsch, A., Bottoms, A. E., Burney, E., \& Wikström, P.-O. (1999). Criminal deterrence and sentencing severity: An analysis of recent research. Oxford, UK: Hart Publishing.

Wikström, P-O. (2008). Deterrence and deterrence experiences: Preventing crime through the fear of punishment. In S. G. Shoham, O. Beck, \& M. Kett (Eds.), International handbook of penology and criminal justice. Boca Ratons, FL: CRC Press.

World Health Organization. (2018, February 19). Road traffic injuries. Retrieved from http://www.who.int/mediacentre/factsheets/fs358/en/ [Accessed 21 April 2018] 


\section{Vicarious Corruption Experience}

1. Someone (car owner, friends, or family, etc.) spoke to the police to stop their .850 case from going to court.

2. Someone (car owner, friends, or family, etc.) spoke to the police to stop them .838 from being arrested for a traffic offence.

3. They paid the police money to avoid being taken to court.

4. They paid the police money to avoid arrest for a traffic offence.

5. Someone (car owner, friends, or family, etc.) spoke to the police to release their vehicle to them.

\section{Self-reported Traffic Violations}

1. You failed to stop when a police officer asked you to stop.

2. You drove your car while drunk.

3. You failed to stop after an accident ('hit and run').

4. You drove your car when your driving licence was still expired.

5. You drove your car without a registered number plate.

6. You failed to stop when the traffic lights showed 'red'.

7. You carried goods that weighed more than your car was allowed to carry ('overloading').

8. You drove your car with no driving licence

9. You intentionally provided wrong information on your driving licence

10. You drove your car faster than the speed limits ('over-speeding') 


\section{Perceived Police Fairness}

1. Decisions officers make are fair. $\quad .756$

2. Officers listen to what I have to say during a traffic stop. $\quad .752$

3. Officers treat me with respect during a road traffic stop. $\quad .742$

4. Officers always act according to road traffic laws. $\quad .650$

5. I am satisfied with the work the police do. $\quad .642$

6. Officers give me a reason for stopping me. $\quad .634$

\section{Personal Corruption Experience}

1. Someone (car owner, friends, or family, etc.) spoke to the police to stop your $\quad .864$ arrest for a traffic offence.

2. Someone (car owner, friends, or family, etc.) spoke to the police to stop your $\quad .836$ case from going to court ('foolish case').

3. Someone (car owner, friends, or family, etc.) spoke to the police to release your vehicle to you.

Note: Principal components factoring with varimax rotation. Only loadings greater than 0.40 are displayed 
Table 1: Descriptive statistics for research variables

\begin{tabular}{|c|c|c|c|c|c|}
\hline & $\begin{array}{c}\text { Valid } \\
n\end{array}$ & $\begin{array}{l}\text { Mean/ } \\
\text { Percent }\end{array}$ & SD & Min & Max \\
\hline \multicolumn{6}{|l|}{ Dependent Variables } \\
\hline Traffic law violations & 400 & 1.272 & .403 & 1 & 3.80 \\
\hline Cooperation with police & 390 & 3.459 & 1.380 & 1 & 5 \\
\hline \multicolumn{6}{|l|}{ Independent Variables } \\
\hline Personal Corruption Experience (PCE) & 402 & 1.552 & .901 & 1 & 4 \\
\hline Vicarious Corruption Experience (VCE) & 381 & 2.328 & 1.116 & 1 & 4 \\
\hline Police Fairness & 411 & 2.923 & .967 & 1 & 5 \\
\hline \multicolumn{6}{|l|}{ Control Variable } \\
\hline Study Site & 413 & & & 1 & 2 \\
\hline Accra & & $55.4 \%$ & & & \\
\hline Kumasi & & $44.6 \%$ & & & \\
\hline Vehicle Ownership (Yes) & 405 & $21.2 \%$ & & 1 & 2 \\
\hline Traffic Crash (Yes) & 386 & $15 \%$ & & 1 & 2 \\
\hline Police Traffic Stops (Yes) & 393 & $82 \%$ & & 1 & 2 \\
\hline
\end{tabular}


Outcome of Stops

No Further Action (NFA)

Arrested

Bribed Officer

Driving Experience

Education

Basic Education

Senior High or Better
342

3

$31.0 \%$

$18.1 \%$

$50.9 \%$

407

12.960

9.789

0.17

56

399

1

2

80.5

19.5 
Table 2: Bivariate correlations between substantive variables

\begin{tabular}{lccccc}
\hline & 1 & 2 & 3 & 4 & 5 \\
\hline 1. Law-breaking behaviour & 1.00 & & & & \\
2. Cooperative Intentions & $-.137^{* *}$ & 1.00 & & & \\
3. Personal Corruption Experience & $.210^{* *}$ & $-.213^{* *}$ & 1.00 & & \\
4. Vicarious Corruption Experience & $.364^{* *}$ & $-.256^{* *}$ & $.465^{* *}$ & 1.00 & \\
5. Police Fairness & .012 & $.364^{* *}$ & $-.167^{* *}$ & $-.202^{* *}$ & 1.00 \\
\hline $\mathrm{N}=373-411 ; * p<.01$ & & & & &
\end{tabular}


Table 3: OLS Estimating Correlates of self-reported traffic violations

\begin{tabular}{|c|c|c|c|c|c|c|}
\hline & \multicolumn{3}{|c|}{ MODEL 1} & \multicolumn{3}{|c|}{ MODEL 2} \\
\hline & $b$ & $\mathrm{SE}$ & $\beta$ & $b$ & $\mathrm{SE}$ & $\beta$ \\
\hline Constant & .131 & .052 & & .129 & .051 & \\
\hline Region & -.036 & .014 & $-.160^{*}$ & -.032 & .014 & $-.142 *$ \\
\hline Vehicle Ownership & -.006 & .016 & -.021 & -.001 & .015 & -.004 \\
\hline Traffic Crash & .032 & .017 & .103 & .029 & .017 & .094 \\
\hline Police Stops & -.005 & .016 & -.018 & -.010 & .016 & -.035 \\
\hline \multicolumn{7}{|l|}{ Stop Outcome $\infty$} \\
\hline Arrestees & .025 & .018 & .087 & .014 & .018 & .050 \\
\hline Bribers & .001 & .015 & .006 & -.003 & .014 & -.014 \\
\hline Education & .001 & .015 & .003 & .003 & .015 & .009 \\
\hline Driving Experience & -.002 & .001 & $-.154 * *$ & -.002 & .001 & $-.133^{*}$ \\
\hline Police Fairness & .009 & .007 & .079 & .006 & .007 & .048 \\
\hline PCE & .023 & .007 & $.186^{* *}$ & .031 & .007 & $.250 * * *$ \\
\hline Police Fairness x PCE & & & & .026 & .006 & $.227 * * *$ \\
\hline$F$-statistic & & & $3.691 * * *$ & & & $5.002 * * *$ \\
\hline Adjusted $R^{2}$ & & & $7.8 \%$ & & & $12.2 \%$ \\
\hline$N$ & & & 318 & & & 318 \\
\hline
\end{tabular}

NOTE: $\infty$ reference category: No further action by police; PCE: Personal Corruption Experience; ${ }^{*} P<.05, * * p<.01, * * * p<.001$ 
Table 4: OLS regressing self-reported traffic violations on vicarious corruption experiences (VCE)

\begin{tabular}{|c|c|c|c|c|c|c|}
\hline & \multicolumn{3}{|c|}{ MODEL 1} & \multicolumn{3}{|c|}{ MODEL 2} \\
\hline & $b$ & $\mathrm{SE}$ & $\beta$ & $b$ & $\mathrm{SE}$ & $\beta$ \\
\hline Constant & .078 & .051 & & .079 & .050 & \\
\hline Region & -.013 & .014 & -.057 & -.009 & .014 & -.040 \\
\hline Vehicle Ownership & .008 & .015 & .030 & .010 & .015 & .036 \\
\hline Traffic Crash & .018 & .017 & .057 & .018 & .017 & .057 \\
\hline Police Stops & -.003 & .016 & -.011 & -.010 & .016 & -.033 \\
\hline \multicolumn{7}{|l|}{ Stop Outcome $\infty$} \\
\hline Arrestees & .015 & .018 & .052 & .010 & .018 & .035 \\
\hline Bribers & .010 & .014 & .046 & .008 & .014 & .034 \\
\hline Education & .013 & .015 & .045 & .012 & .015 & .041 \\
\hline Driving Experience & -.002 & .001 & $-.151 * *$ & -.001 & .001 & $-.120 *$ \\
\hline Police Fairness & .012 & .007 & .107 & .010 & .007 & .090 \\
\hline VCE & .036 & .006 & $.362 * * *$ & .036 & .006 & $.363 * * *$ \\
\hline Police Fairness x VCE & & & & .019 & .005 & $.183^{* *}$ \\
\hline$F$-statistic & & & $6.376 * * *$ & & & $7.091 * * *$ \\
\hline Adjusted $R^{2}$ & & & $14.7 \%$ & & & $17.6 \%$ \\
\hline$N$ & & & 313 & & & 313 \\
\hline
\end{tabular}


Table 5: OLS Estimating the Correlates of Willingness to cooperate with police in tackling traffic violations

\begin{tabular}{|c|c|c|c|c|c|c|}
\hline & \multicolumn{3}{|c|}{ MODEL 1} & \multicolumn{3}{|c|}{ MODEL 2} \\
\hline & $b$ & $\mathrm{SE}$ & $\beta$ & $b$ & $\mathrm{SE}$ & $\beta$ \\
\hline Constant & 2.970 & .588 & & 2.957 & .582 & \\
\hline Region & .705 & .157 & $.254 * * *$ & .736 & .156 & $.265 * * *$ \\
\hline Vehicle Ownership & -.298 & .177 & -.088 & -.263 & .176 & -.078 \\
\hline Traffic Crash & -.125 & .196 & -.032 & -.145 & .194 & -.038 \\
\hline Police Stops & -.081 & .185 & -.023 & -.118 & .183 & -.033 \\
\hline \multicolumn{7}{|l|}{ Stop Outcome $\infty$} \\
\hline Arrestees & -.397 & .209 & -.111 & -.477 & .210 & $-.133 *$ \\
\hline Bribers & .165 & .165 & .060 & .133 & .164 & .048 \\
\hline Education & .038 & .174 & .011 & .050 & .172 & .014 \\
\hline Driving Experience & -.001 & .007 & -.010 & .000 & .007 & .004 \\
\hline Police Fairness & .472 & .077 & $.331 * * *$ & .445 & .077 & $.312 * * *$ \\
\hline PCE & -.173 & .081 & $-.113^{*}$ & -.113 & .083 & -.074 \\
\hline Police Fairness x PCE & & & & .193 & .073 & $.138 * *$ \\
\hline$F$-statistic & & & $10.251 * * *$ & & & $10.136^{* * *}$ \\
\hline Adjusted $R^{2}$ & & & $22.5 \%$ & & & $24.0 \%$ \\
\hline$N$ & & & 318 & & & 318 \\
\hline
\end{tabular}

NOTE: $\infty$ reference category: No further action by police; PCE: Personal Corruption Experience; $* P<.05, * * p<.01, * * * p<.001$ 
Table 6: OLS regressing willingness to cooperate with police on vicarious corruption experience (VCE)

\begin{tabular}{|c|c|c|c|c|c|c|}
\hline & \multicolumn{3}{|c|}{ MODEL 1} & \multicolumn{3}{|c|}{ MODEL 2} \\
\hline & $b$ & $\mathrm{SE}$ & $\beta$ & $b$ & $\mathrm{SE}$ & $\beta$ \\
\hline Constant & 3.036 & .608 & & 3.042 & .604 & \\
\hline Region & .682 & .168 & $.246^{* * *}$ & .711 & .167 & $.256^{* * *}$ \\
\hline Vehicle Ownership & -.315 & .182 & -.093 & -.303 & .181 & -.090 \\
\hline Traffic Crash & -.069 & .199 & -.018 & -.068 & .198 & -.018 \\
\hline Police Stops & -.101 & .186 & -.028 & -.148 & .187 & -.041 \\
\hline \multicolumn{7}{|l|}{ Stop Outcome $\infty$} \\
\hline Arrestees & -.356 & .212 & -.099 & -.393 & .212 & -.110 \\
\hline Bribers & .127 & .168 & .046 & .107 & .167 & .039 \\
\hline Education & -.002 & .177 & -.001 & -.011 & .176 & -.003 \\
\hline Driving Experience & -.001 & .007 & -.009 & .001 & .007 & .009 \\
\hline Police Fairness & .470 & .078 & $.329 * * *$ & .455 & .078 & $.319 * * *$ \\
\hline VCE & -.116 & .072 & -.093 & -.115 & .071 & -.093 \\
\hline Police Fairness x VCE & & & & .138 & .064 & $.110^{*}$ \\
\hline F-statistic & & & $9.832 * * *$ & & & $9.466 * * *$ \\
\hline Adjusted $R^{2}$ & & & $22 \%$ & & & $22.9 \%$ \\
\hline$N$ & & & 313 & & & 313 \\
\hline
\end{tabular}

